\title{
Experimental study on the analysis of nanocellulose treated water in Yola metropolis, Nigeria
}

\author{
Linus N. Okoro ${ }^{1 *}$, Bolade O. Agboola ${ }^{2}$, Precious O. Yakubu ${ }^{2}$ \\ Department of Chemistry, Alex Ekwueme Federal University Ndufu-Alike Ikwo, Ebonyi State, \\ Nigeria \\ Department of Petroleum Chemistry, American University of Nigeria, Yola
}

\begin{abstract}
In this study, cellulose from sugarcane bagasse and wood pulp were converted to nanocellulose and utilized to treat water from different sources within Yola Metropolis to study the efficacy of both methods. From the analysed water parameters, both nanocellulose materials were effective in treating contaminated water. They showed the capability of reducing the concentrations of the various tested parameters such as Total Dissolved Solids (TDS), Nitrate, Chloride, and Nephelometric Turbidity Units (NTU). Interestingly, analysis of the heavy metal concentrations before and after water treatment with the nanocellulose, showed very significant reduction of the heavy metals. This is encouraging as we explore more efficient methods of water treatment, in order to tackle rising cases of lead and other heavy metal poisoning in Nigeria due to illegal mining activities and deregulated industrial activities.
\end{abstract}

Keywords: Nanocellulose, Water treatment, Sugarcane bagasse, Wood pulp, Heavy metals

\section{Résumé}

Dans cette recherche, la cellulose de la bagasse de canne à sucre et de la pulpe de bois a été converties en nanocellulose et utilisées pour l'épuration d'eau de différentes sources au sein de Yola Metropolis afin d'étudier l'efficacité des deux méthodes. D’après les paramètres d'eau analysés avec les deux types de nanocelluloses étaient efficaces dans le traitement de l'eau contaminée. Ils ont considérablement réduit les concentrations des différents contaminants testés tels que le TDS, le nitrate, le chlorure et le NTU. En effet, l'analyse de la concentration en métaux lourds avant et après le traitement de l'eau avec la nanocellulose a montré une réduction très significative des métaux lourds. C'est une bonne chose car nous explorons des méthodes plus efficaces de traitement de l'eau, pour lutter contre l'augmentation des cas d'empoisonnement au plomb et à d'autres métaux lourds au Nigeria en raison d'activités minières illégales et d'activités industrielles non réglementées.

Received: 07/07/2021

Accepted: 26/08/2021

DOI: https://dx.doi.org/10.4314/jcas.v17i2.2

(C) The Authors. This work is published under the Creative Commons Attribution 4.0 International Licence. 


\subsection{INTRODUCTION}

Access to clean water, in developing countries is gradually decreasing as the activities of industries are increasing and affecting the surrounding water bodies. The need for more ways to purify water has become a necessity. Considering that not everyone can afford clean water, or the opportunity of buying water filters of different brands, it has become the yarning desire of those in the communities to afford clean water no matter the situation. Hence a rapid innovation for water treatment that even the poor man can afford is required. Lack of portable water can lead to various diseases such as lead poisoning, polyomavirus infection, hepatitis $\mathrm{A}$ and other deadly diseases (WHO 1993; 2008; 2019).

Cellulose is one of the world's most abundant natural and renewable biopolymer resources that is present in trees, plants and bacteria. In the present investigation, sugarcane bagasse and wood were used as starting materials since they contain a high level of cellulose.

Nanotechnology is the field of science which is evolving rapidly and involves the synthesis and development of various nano materials such as nanocellulose, nanoparticles, and nanofibers (Hasan, 2015). Nanotechnology offers a great potential for the use of new materials for the treatment of surface water and ground water and wastewater contaminated by toxic, organic and inorganic substances (Lucie Kriklavova, 2011). Cellulose, one of the most abundant biopolymers on earth, occurs in wood, cotton, hemp and other plant-based materials (Khatoon Maddahy, 2012). In recent times the production of nano-scale cellulose fibers and their application in composite materials has gained a massive attention because of its high strength and stiffness combined with low weight biogradability and renewability (Khatoon Maddahy, 2012). Nanocellulose can be produced using acid hydrolysis, alkaline extraction, cryocrushing, enzyme -assisted hydrolysis, steam explosion, high pressure homogenization and bleaching (Chaitali V. Mohod, 2013). To produce nanocellulose the method which is mostly used is acid hydrolysis (Cintil Jose Chirayil, 2013). These synthesized products have a diameter of about $2-20 \mathrm{~nm}$ and a width of about 100-600nm.

Sugarcane bagasse is an agricultural residue, which is rich in lignocellulose, cellulose, hemicellulose, and other compositions. It is majorly known to produce glucose, xylose, ethanol and methane, table 1.1 (A.A Guilherme, 2014).

Table 1.1: Chemical composition of Sugarcane Bagasse

\begin{tabular}{ll}
\hline Component & Percentage \\
\hline Cellulose & $45-55 \%$ \\
Hemicellulose & $20-25 \%$ \\
Lignin & $18-24 \%$ \\
Ash & $1-4 \%$ \\
Waxes & $<1 \%$ \\
\hline
\end{tabular}

In wood, 30-40 cellulose polymer chains aggregate into nanofibrils; this is also referred to as elementary fibrils or microfibrils, it is normally as wide as $3-5 \mathrm{~nm}$. Within each of these nanofibrils, there are regions where the cellulose chains are arranged in highly ordered crystalline structures, and regions that are amorphous (Salajkova, 2013).

Table 1.2: Chemical composition of Wood pulp

\begin{tabular}{ll}
\hline Component & Percentage \\
\hline Cellulose & $42 \%$ \\
Hemicellulose & $27 \%$ \\
Lignin & $28 \%$ \\
Extractives & $1-4 \%$ \\
\hline
\end{tabular}

\subsection{Nanocellulose}

Generally, nanocellulose is a long, thread-like cellulose nano-fibers (CNF), ribbon- like bacterial nanocellulose (BNC) or short, rigid rods called cellulose nanocrystals (CNC) (Hasan, 2015) (Khatoon Maddahy, 2012). Some of the 
advantages of nanocellulose include abundant natural nanomaterials, renewable, biodegradable \& biocompatible, high strength \& modulus, high aspect ratios and high surface areas, chemical functionality \& modification, as well as dimensional stability (Hasan, 2015)

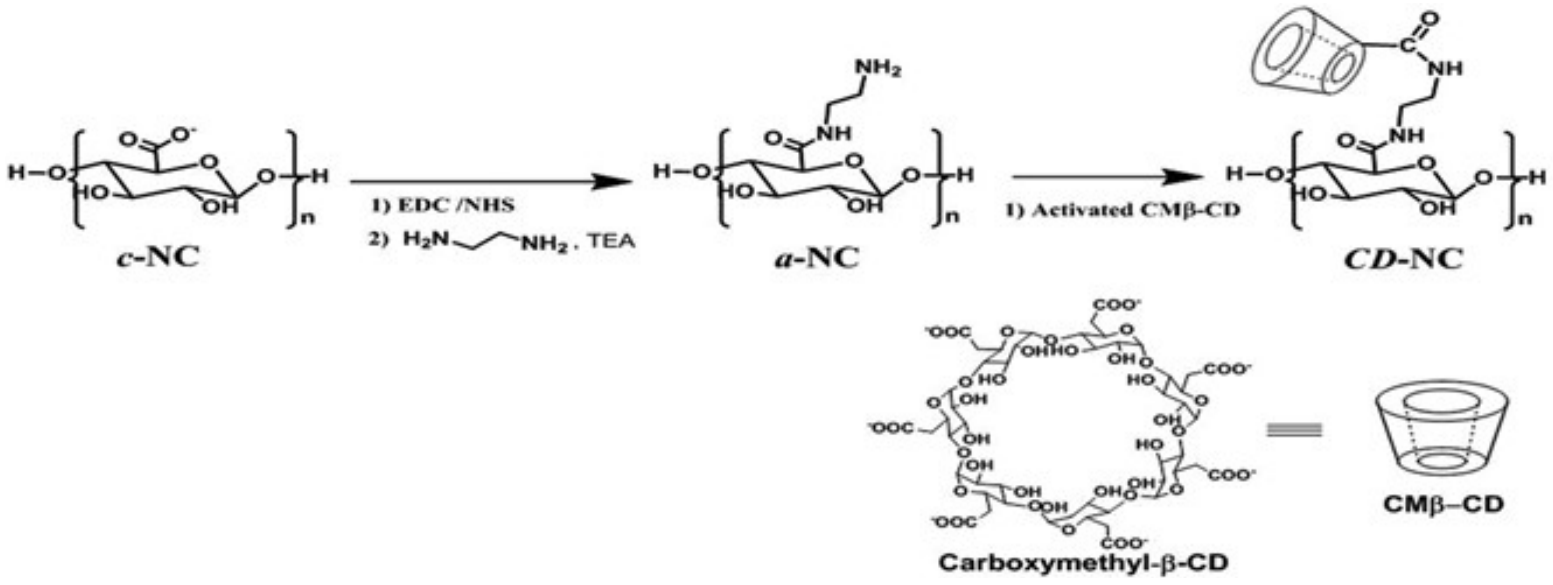

Figure 1.2: A converted nanocellulose using â-Cyclodextrin (Xiudan H. et al, 2015)

\subsection{Water Treatment}

When choosing a water treatment method, a major factor that should be considered is the cost of the method. Some of the existing methods of water treatment are boiling, domestic chlorination, slow sand filtration and storage and sedimentation (Brikke.F, 1997) can be expensive and therefore not widely affordable.

\subsection{Acid Hydrolysis}

Using acid hydrolysis for nanocellulose production, subjects the cellulose microfibrils to transverse cleavage along the amorphous regions (Dussán K. J., 2014) (Fan Liang-tseng, 1987).

\subsection{Problem statement, Aims and Objectives}

In recent times, there has been increasing cases of water contaminated water in Nigeria, because of the rise in industrial activities. Majority of these industries are situated close to water bodies, where the waste from these industries is discharged into the surrounded water bodies, affecting not only the community but others in general. This has increased the demand for clean water in the communities, and as such cheaper and more effective methods of water purification are being birthed every day. The aim of this research was to develop an efficient and affordable materials for the purification of wastewater. The objectives were to synthesize nanocellulose from sugar cane bagasse and pulp wood respectively and study their efficiency in purifying contaminated water from various sources in Yola Metropolis.

\subsection{MATERIALS AND METHODOLOGY}

The starting materials used for this project include Water samples, sugarcane bagasse and wood pulp. The water samples were obtained from River Benue, a well at Shagari in Yola, Adamawa State, Nigeria and a borehole at Faro Water Company, Yola. The Sugarcane Bagasse was obtained from Yola market and the Wood pulp was obtained from Kazuwa Katako (wood market) in Jimeta, Yola.

\subsection{Apparatus}

The apparatus used for this project includes a reflux condenser, blender, mortar and pestle, round bottom flask, beakers, distillation funnel and heating mantel. For water parameter test, Venier probes for total dissolved solid, $\mathrm{pH}$, chloride, nitrate, and turbidity were used and for total water hardness a burette, stirring bar, and beakers. 
High quality analytical grade reagents were used throughout the process and were not purified further.

\subsection{Water parameter test}

Using the various Venier probes and a computer system, the collected water samples were analyzed for the following parameters, Total dissolved solid, $\mathrm{pH}$, chloride, nitrate, turbidity and total water hardness (Rahmanian 2015).

\subsection{Heavy metal Test}

Using 210 Atomic Absorption Spectrometer (AAS) from Buck Scientific, the level of heavy metals was analyzed. For this project the following metals where tested iron $(\mathrm{Fe})$, copper $(\mathrm{Cu})$, cadmium $(\mathrm{Cd})$, and Zinc (Zn).

\subsection{Preparatory Process}

Using a blender, the wood pulp was ground into smaller bits; while using mortar and pestle the sugarcane bagasse was pounded into smaller bits. The wood pulp was stored in a dried area, while the sugarcane bagasse was placed under the sun for complete drying. The dried wood pulp and sugarcane bagasse were soaked in distilled water for 24 hours, after which they were moved into a solution of $0.25 \mathrm{M}$ of sodium hydroxide for 18hours.

The purified wood pulp and sugarcane bagasse were rinsed using distilled after they were removed from the sodium hydroxide. 300 grams was measured respectively for each product and a reflux condensation was carried out in a round bottom flask, containing a $20 \%$ nitric acid and $80 \%$ ethanol mixture, for 3 hours. At 1-hour intervals, the solution was changed to a fresh one. A color change was observed from dark brown to light yellow, as the refluxing proceeded.

At the end of 3hours the suspension was filtered and washed with distilled water several times, till the $\mathrm{pH}$ is observed to turn neutral or slightly basic (using the $\mathrm{pH}$ Probe and Ammonia).

Finally, it was centrifuged for 30minutes at 8,500 $\mathrm{rpm}$, and then the residue was dried at $75^{\circ} \mathrm{C}$ for 15-30 minutes. The same procedure was repeated for wood pulp.

A filteration column was setup using the nanocellulose and cotton wool. Atomic Absorption Spectrometer was used to check for heavy metals analysis.

\subsubsection{Calculation of \% yields of the nanocellulose}

Percentage yield $=\frac{\text { actual yield }}{\text { theoretical yield }} * 100 \%$

For Sugarcane bagasse Nanocellulose

Trial $1=\%$ yield $=\frac{1.0819 \mathrm{grams}}{300 \mathrm{grams}} * 100 \%=0.36 \%$

Trial $2=\%$ yield $=\frac{1.0719 \mathrm{grams}}{300 \mathrm{grams}} * 100 \%=0.35 \%$

For Wood pulp Nanocellulose

Trial $1=\%$ yield $=\frac{1.0275 \mathrm{grams}}{300 \mathrm{grams}} * 100 \%=0.34 \%$

Trial $2=\%$ yield $=\frac{1.025 \mathrm{grams}}{300 \mathrm{grams}} * 100 \%=0.34 \%$

\subsubsection{Water parameter standards}

The water parameters determined in this research includes the following:

Total Dissolved Solid (TDS): According to the world health organization (WHO 1993) the acceptable limit of TDS in water is $500 \mathrm{mg} / 1$.

Chloride: The acceptable limit of chloride in water is $250 \mathrm{mg} / 1$.

Nitrate: The acceptable level of nitrate is 10$50 \mathrm{mg} / 1$ or less.

Turbidity: The acceptable limit for turbidity is $<5 \mathrm{NTU}$.

$p H$ : The acceptable limit of $\mathrm{pH}$ in a water sample is 6.5-8.5. 
Table 2.1: Acceptable Water Standards by World Health Organization (WHO 1993)

\begin{tabular}{|l|l|l}
\hline Water Parameter & Acceptable limit & Effects \\
\hline Nitrate & $10-40 \mathrm{mg} / 1$ & $\begin{array}{l}\text { In a case where the concentration is more than accepter } \\
\text { it can cause methemoglobinemaia (blue baby disease) it } \\
\text { infants }\end{array}$ \\
\hline Chloride & $250 \mathrm{mg} / 1$ & $\begin{array}{l}\text { If it exceeds the limit it would be salty or brackish tast } \\
\text { it would be corrosive, blackens and pits stainless steel. }\end{array}$ \\
\hline Turbidity & $\begin{array}{l}\text { More than the acceptable limits indicate contaminatio } \\
\text { and the water would be cloudy. }\end{array}$ \\
\hline $\mathrm{pH}$ & $\begin{array}{l}\text { Low pH can cause pitting of pipes and fixtures or } \\
\text { metallic taste. This means the metals are being dissolvec } \\
\text { At high pH the water would have a soda taste anı } \\
\text { slippery feel. }\end{array}$ \\
\hline
\end{tabular}

\subsection{RESULTS AND DISCUSION}

From table 3.1, 3.2 and 3.3, slight to significant decrease in concentrations of the analyzed water parameters were observed in the Faro borehole, River Benue and Shagari well water samples respectively, after treatment with both the wood pulp and the sugarcane Nanocellulose.

Table 3.1: Results of analysis of treated Faro Borehole water using Nanocellulose

\begin{tabular}{|l|l|l|l}
\hline Faro Borehole Water & Before Treatment & $\begin{array}{l}\text { After Treatment } \\
\text { Using } \\
\text { Wood pulp }\end{array}$ & $\begin{array}{l}\text { After Treatmen } 1 \\
\text { Using } \\
\text { Sugarcane Baga: }\end{array}$ \\
\hline Total dissolved solid (TDS) & $31 \mathrm{mg} / 1$ & $22 \mathrm{mg} / 1$ & $27 \mathrm{mg} / 1$ \\
\hline $\mathrm{pH}$ & 7.44 & 7.0 & 6.3 \\
\hline Chloride & $0.3 \mathrm{mg} / 1$ & $0.1 \mathrm{mg} / 1$ & $0.2 \mathrm{mg} / 1$ \\
\hline Nitrate & $0.1 \mathrm{mg} / 1$ & $0.0 \mathrm{mg} / 1$ & $0.0 \mathrm{mg} / 1$ \\
\hline Turbidity & $31.9 \mathrm{NTU}$ & $1.5 \mathrm{NTU}$ & $0.3 \mathrm{NTU}$ \\
\hline
\end{tabular}

Table 3.2: Results of analysis of treated River Benue water using Nanocellulose

\begin{tabular}{|l|l|l|l}
\hline River Benue Water & Before Treatment & $\begin{array}{l}\text { After Treatment Using } \\
\text { Wood pulp }\end{array}$ & $\begin{array}{l}\text { After Treatment Usi } \\
\text { Sugarcane Bagasse }\end{array}$ \\
\hline Total dissolved solid (TDS) & $261 \mathrm{mg} / 1$ & $18.9 \mathrm{mg} / 1$ & $230 \mathrm{mg} / 1$ \\
\hline $\mathrm{pH}$ & 8.08 & 7.74 & 7.46 \\
\hline Chloride & $14.4 \mathrm{mg} / 1$ & $3.3 \mathrm{mg} / 1$ & $5.1 \mathrm{mg} / 1$ \\
\hline Nitrate & $0.1 \mathrm{mg} / 1$ & $0.0 \mathrm{mg} / 1$ & $0.0 \mathrm{mg} / 1$ \\
\hline Turbidity & $166.5 \mathrm{NTU}$ & $1.7 \mathrm{NTU}$ & $6.7 \mathrm{NTU}$ \\
\hline
\end{tabular}


Based on the World Health Organization (WHO) standards, it is observed that the analyzed parameters for the treated water samples from the three sources fall within the acceptable standards (WHO 1993).

The concentration values also correlate with the acceptable limits according to the World Health
Organisation standards, except the turbidity value after treatment with sugarcane bagasse nanocellulose, as shown in table 3.2 (W.H.O. 1993). For all the analyzed parameters, it is however observed, that they fall within the acceptable standards.

\section{Table 3.4: Heavy metal Analysis for Shagari Well Water (units in $\mathrm{mg} / \mathrm{L}$ )}

\begin{tabular}{|l|l|l|l|}
\hline Shagari Well Water & $\begin{array}{l}\text { Before Treatment } \\
(\mathrm{mg} / \mathrm{L})\end{array}$ & $\begin{array}{l}\text { After Treatment } \\
\text { Using } \\
\text { Sugarcane Bagasse }\end{array}$ & $\begin{array}{l}\text { After Treatment } \\
\text { Using } \\
\text { Wood pulp }\end{array}$ \\
\hline Copper $(\mathrm{Cu})$ & 0.06 & 0.02 & 0.03 \\
\hline Zinc $(\mathrm{Zn})$ & 0.04 & 0.02 & 0.01 \\
\hline Cadmium $(\mathrm{Cd})$ & 0.14 & 0.00 & 0.00 \\
\hline Iron $(\mathrm{Fe})$ & 0.29 & 0.07 & 0.09 \\
\hline
\end{tabular}

Table 3.5: Heavy metal Analysis for Faro Borehole Water

\begin{tabular}{|l|l|l|l|}
\hline Faro Borehole & Before Treatment & $\begin{array}{l}\text { After Treatment } \\
\text { Using } \\
\text { Sugarcane Bagasse }\end{array}$ & $\begin{array}{l}\text { After Treatment } \\
\text { Using } \\
\text { Wood pulp }\end{array}$ \\
\hline Copper $(\mathrm{Cu})$ & $0.04 \mathrm{mg} / 1$ & $0.01 \mathrm{mg} / 1$ & $0.03 \mathrm{mg} / 1$ \\
\hline Zinc $(\mathrm{Zn})$ & $0.11 \mathrm{mg} / 1$ & $0.04 \mathrm{mg} / 1$ & $0.03 \mathrm{mg} / 1$ \\
\hline Cadmium $(\mathrm{Cd})$ & $0.26 \mathrm{mg} / 1$ & $0.00 \mathrm{mg} / 1$ & $0.00 \mathrm{mg} / 1$ \\
\hline Iron $(\mathrm{Fe})$ & $0.10 \mathrm{mg} / 1$ & $0.05 \mathrm{mg} / 1$ & $0.02 \mathrm{mg} / 1$ \\
\hline
\end{tabular}

Analysis results in table 3.4 and 3.5 indicate that effective water treatment has been carried out using the synthesized nanocellulose; as there was observed significant reduction in the heavy metals concentration (fig. 3.4 and 3.5).

Comparing the standards by W.H.O, the treated water samples have very low heavy metal toxicity, and all parameters fall within the recommended standards implying safe water for human consumption. Both the sugarcane bagasse nanocellulose and the wood pulp nanocellulose generally showed the ability to effectively reduce the heavy metal concentration in the analyzed water sample. 


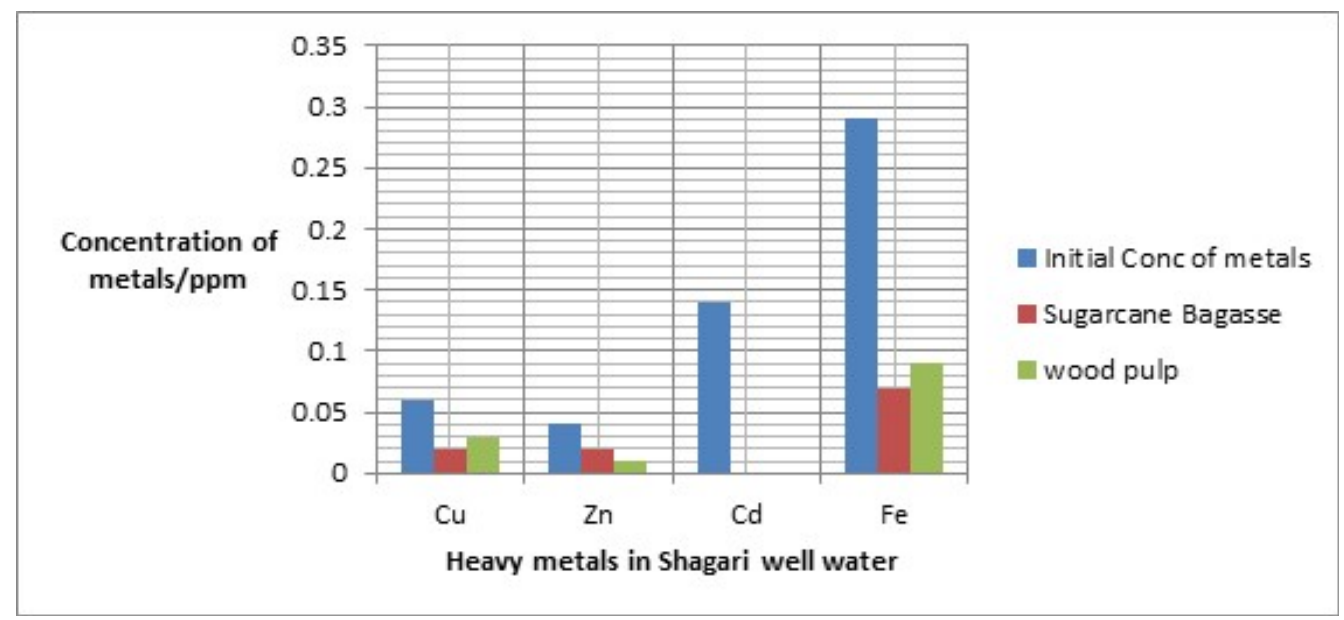

Figure 3.4: Shagari well water analysis

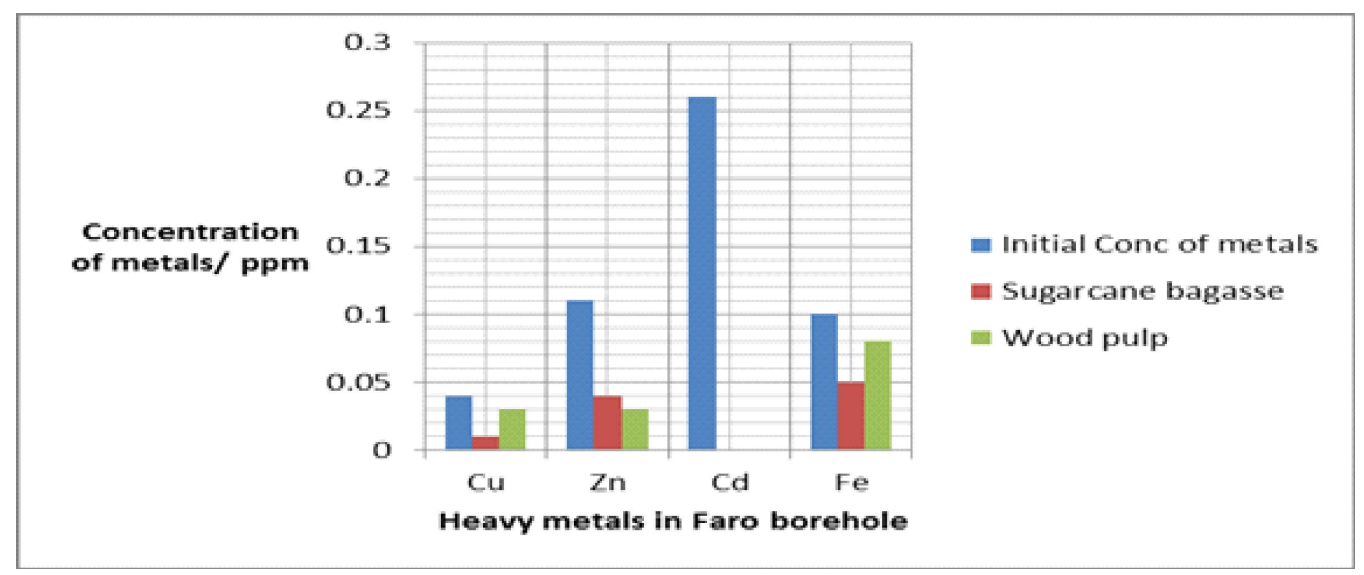

Figure 3.5: Faro borehole water heavy metal analysis

UV and IR analysis were obtained for the synthesized nanocellulose. We observed the absorption peaks attributed to the $\mathrm{O}-\mathrm{H}$ and $\mathrm{C}-\mathrm{H}$ stretching as shown in figures 3.6 and 3.7 (Yan etal, 2021).

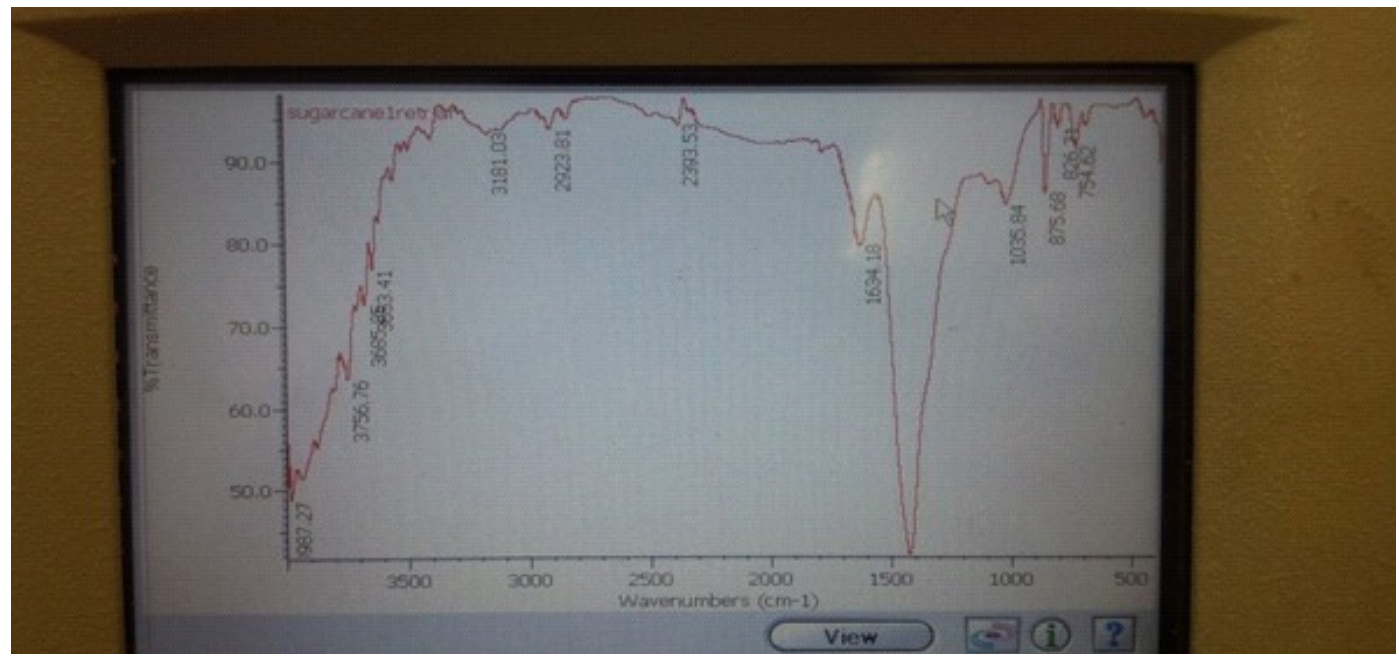

Figure 3.6: IR spectra of the synthesized sugarcane bagasse 
Table 3.6: Tabular explanation of fig. 3.6 spectra

\begin{tabular}{|l|l|}
\hline Type of Vibration & Frequency \\
\hline 3685.96 & O-H (free) \\
\hline 3633.41 & O-H (free) \\
\hline 3181.03 & Alkenes Stretch \\
\hline 2923.81 & C-H Alkanes \\
\hline 23993.53 & Carboxylic acid \\
\hline 1634.18 & C=C Aromatic \\
\hline 1035.84 & C-O Alcohol \\
\hline 875.68 & Aromatic \\
\hline 826.71 & C-X Chloride \\
\hline 754.62 & C-X Chloride \\
\hline
\end{tabular}

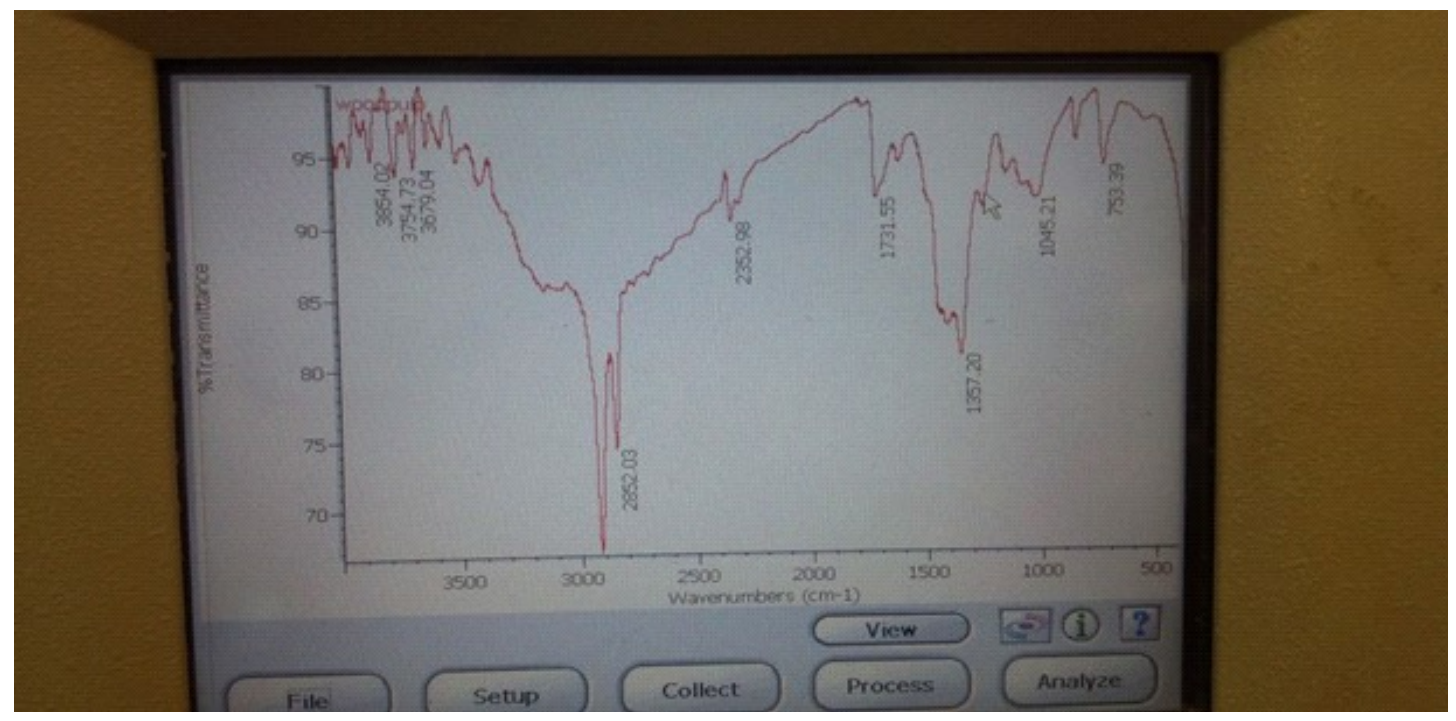

Figure 3.7: IR spectra of the synthesized wood pulp

Table 3.7: Tabular explanation of the fig. 3.7 spectra

\begin{tabular}{|l|l|}
\hline Type of Vibration & Frequency \\
\hline 2852.03 & C-H Aldehyde \\
\hline 2352.98 & O-H Carboxylic acid \\
\hline 1731.55 & C=O Aldehyde \\
\hline 1357.20 & N=O Nitro $\left(\mathrm{R}-\mathrm{NO}_{2}\right)$ \\
\hline 1045.21 & C-X fluoride \\
\hline 753.39 & C-X Chloride \\
\hline
\end{tabular}

Absorption peaks of $\mathrm{O}-\mathrm{H}$ vibration of absorbed water; $\mathrm{C}-\mathrm{H}$ and $\mathrm{C}-\mathrm{O}$ vibrations peaks which are found in the polysaccharide rings of cellulose showed around $1382 \mathrm{~cm}^{-1}$. Tables 3.6 and 3.7 show the absorption peaks of other detected functional groups. Comparing the analysis results with published spectra analysis of synthesized nanocellulose, shows similar absorptions (Sun 2020; Yan etal 2021). Figure 3.8 shows the UV-Vis spectrophotometer spectra of the synthesized nanocellulose. 


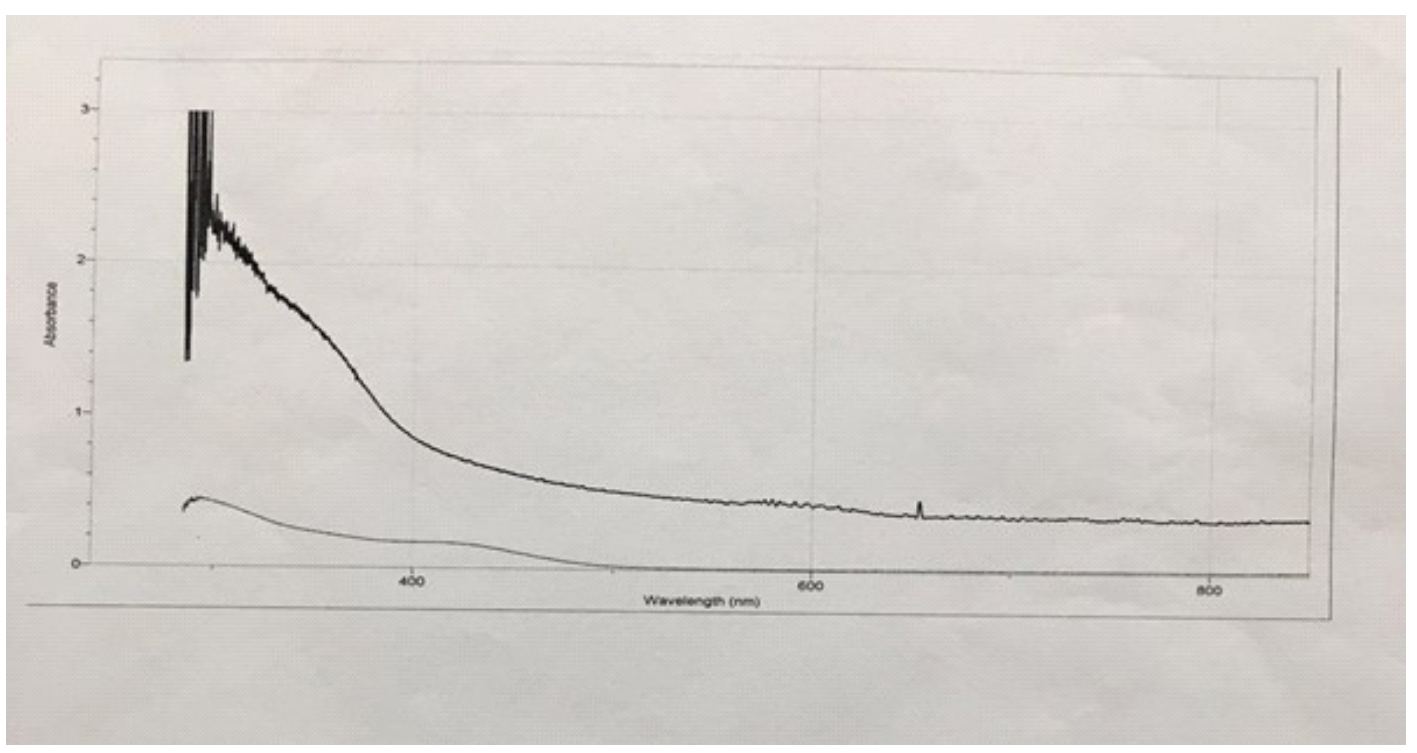

Figure 3.8: UV-Vis spectra of nanocellulose.

\subsection{CONCLUSION RECOMMENDATION}

This work was focused on utilizing synthesized Nanocellullose from wood pulp and sugar cane bargasse for purification of water samples from three different sources in Yola Metropolis. From the results obtained, it is observed that both Nanocellulose materials proved effective in reducing the level of heavy metal contamination as well as in reducing the other tested water parameters such as TDS, turbidity, and Chlorides. The UV and IR absorption spectra for the synthesized nanocellulose compared favourably with previously published spectra analysis of synthesized nanocellulose absorptions (Sun 2020; Yan etal 2021). It is recommended that further work be carried out in particular to improve the percentage yield of the nanocellulose as well as characterization to obtain electron micrographs. This is a promising research area that requires further exploration.

\section{Acknowledgement}

We appreciate the financial and instrumentation support obtained from the American University of Nigeria, which helped immensely in this research work.

\section{References}

Borjesson, M. and Westman, G. (2015) Crystalline Nanocellulose-Preparation, Modification, and Properties. Cellulose-Fundamental Aspects and Current Trends, INTECH, 201; 159-191. https:/ /doi.org/10.5772/61899

Brandon C. Knott, Majid Haddad Momeni, Michael F. Crowley, Lloyd F. Mackenzie, Andreas W. Götz, Mats Sandgren, Stephen G. Withers, Jerry Ståhlberg, and Gregg T. Beckham (2014) Journal of the American Chemical Society 136 (1), 321329

Brikke, F. (1997). Linking technology choice with operation and maintenance for low-cost water supply and sanitation; IRC International Water and Sanitation Centre: The Hague.

Chigome, S.Torto, N. Analytica Chimica Acta (2011), 706, 25-36.

De Souza, A.; Leite, D.; Pattathil, S.; Hahn, M.; Buckeridge, M. (2012) BioEnergy

Research 6, 564-579. 
Dussan, K.; Silva, D.; Morae, E.; Arruda, P.; Felipe, M. (2014) Chemical Engineering Transactions 38, 433-437.

Fan, L.; Gharpuray, M.; Hyun Lee, Y. (1987) Springerlink 121-148.

Frone, A.; Panaitescu, D.; Donescu, D. (2011) Science Bull Series 73, 1-20.

Guilherme, A.; Dantas, P.; Santos, E.; Fernandes, F.; Macedo, G. (2015) Brazilian Journal of Chemical Engineering 32, 23-33.

Khatoon, N.; Rameezani, O.; Kermanian, H. (2012) Proceedings of the 4th International Conference on Nanostructure 87-89.

Luduena, L.; Fasce, D.; Alvarez, V.; Stefani, P. (2016) Bioresources. Com. 6, 1440-1453.

Morán, J.; Alvarez, V.; Cyras, V.; Vázquez, A. Cellulose (2007), 15, 149-159.

Mtui, G. African Journal of Biotechnology (2016), 8, 1398-1415.

Rahmanian, Siti Hajar Bt Ali, M.

Homayoonfard, N. J. Ali, M. Rehan, Y. Sadef, A. S. Nizami, (2015) Journal of

Chemistry, vol., 10 pages.

Randall, J.Vonderbrink, S.(2004) Advanced chemistry with Vernier, Vernier Software \& Technology: Beaverton.

Saelee, K.; Yingkamhaeng, N.; Nimchua, T.; Sukyai, P. The 26th Annual Meeting of the Thai Society for Biotechnology and International Conference (2016), 1-7.

Salas, C.; Nypelö, T.; Rodriguez-Abreu, C.; Carrillo, C.; Rojas, O. Current Opinion in Colloid \& Interface Science 2014, 19, 383-396.

Sun, L., Yang, S., Qian, X. et al. (2020) Cyclodextrin and cellulose combination product developed by click chemistry: fascinating design for inclusion of ciprofloxacin. Cellulose 27, 59555970 .

Suopajarvi, T. Functionalized nanocelluloses in wastewater treatment applications; 1st ed.; University of Oulu Graduate School: Finland, (2016); pp. $45-47$.

Wulandari W., A Rochliadi and I M Arcana; (2016) IOP Conf. Series: Materials Science and Engineering 107; 1-7

WHO; Guidelines for Drinking-Water Quality Second Edition - Volume 1 - Recommendations, 1993 https://www.who.int/ water_sanitation_health/dwq/2edvol1i.pdf.

WHO Library Cataloguing-in-Publication Data Guidelines for drinking-water quality [electronic resource]: incorporating 1 st and 2 nd addenda, Vol.1, Recommendations. - 3rd ed, 2008.

WHO; Lead poisoning and health, 2019; https:/ /www.who.int/news-room/fact-sheets/detail/ lead-poisoning-and-health.

Xiudan Hou, Licheng Wang, Xiaofen Tang, Chunming Xiong, Yong Guo and Xia Liu Analyst, (2015), 140, 6727; DOI: $10.1039 /$ C5AN01030F

Yan, N., Chai, XS. \& Runge, T. (2021) A simple multi wavelength spectroscopic method for the determination of carboxyl group content in nanocellulose. Cellulose 28, 2805-2811. 